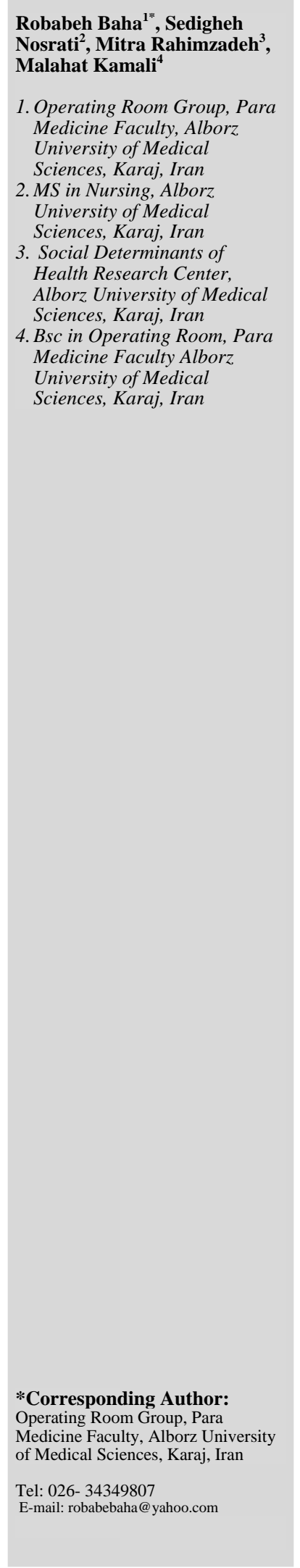

\section{Survey of Medication Errors in Operating Rooms Staff with Some organizational and Demographic Characteristics}

Received:18 Jul. 2017; Accepted:23 Oct. 2017

Introduction: Medication errors are the factors threatening the safety of patients. Medical errors led to increased mortality, prolonged hospital stay and increased healthcare costs is in the hospital. The aim of this study was to determine of medication errors in operating rooms staff with Some organizational and demographic characteristics

Method: This is a descriptive-analytic study conducted on 201 operating rooms staff of selected hospitals of Alborz University of Medical Sciences. The study population members are staffs who working in the operating room of the Hospital of Alborz University of Medical Sciences. The sampling method wa census and its conducted in 2016. The data were collected using questionnaire. After collection, data analysis was performed by using descriptive- analytical statistical and SPSS version 19 .

Findings: The average number of medication errors as in three months per staff was 2.2 and the average of medication errors reported was 0.06 . Medication errors $(p=0.048)$ and errors reported $(p=0.000)$ by the operating room staff were significantly correlated with working conditions. The demographic characteristics of employment in different sectors and work experience were associated with medication errors.

Discussion: Regarding the relationship between working conditions with medication errors, Review and understanding of working conditions and adjusted them help reduce medication errors. It seems that health care authorities, in order to reduce these errors should identify the causes and apply strategies.

Keywords: Medication errors, Operating room staff, Drug administration 


\section{بررسى وقوع و كَزارش خطاهاى دارويى كار كنان اتاق عمل و ارتباط آن با برخى مشخصdهاى فردى و سازمانى}

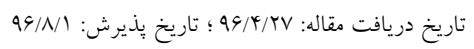

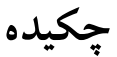

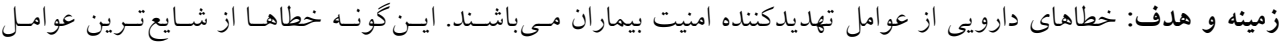

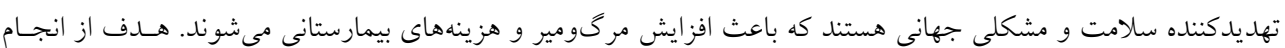

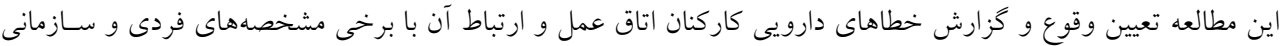
در بيمارستانهاى دانشخاه علوم يزشكى البرز بوده است.

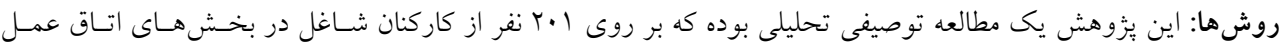

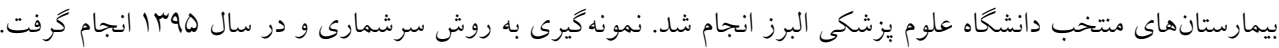

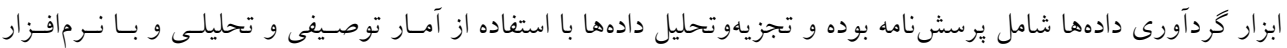

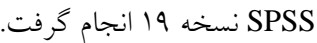

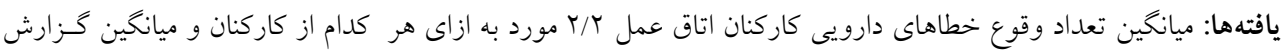

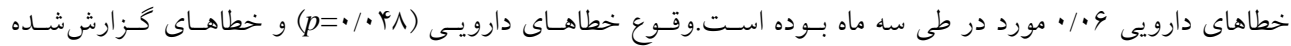

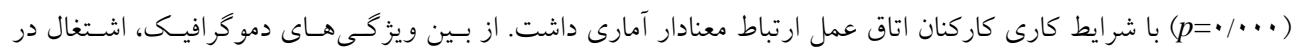

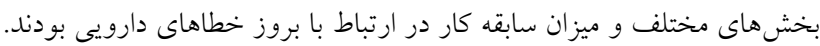

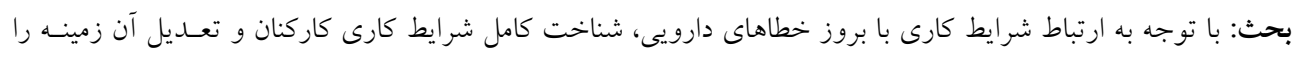

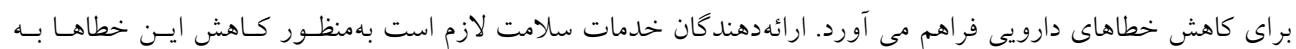
شناسايى علل وقوع و كاربرد راهبردهايى جهت كاهش آنس آنها بيردازند. كلمات كليدى: خطاهاى دارويى، كار كنان اتاق عمل، دارودرمانى

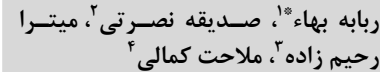

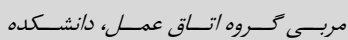

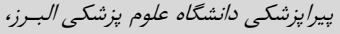
كرج، ايران

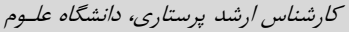
بزشكى البرز، كرج، ايران

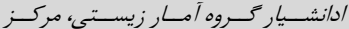

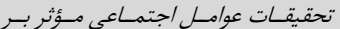

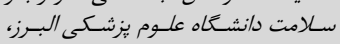
كرج، ايران

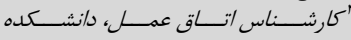

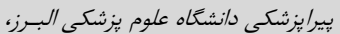
كرج، بيران 
عوامل مؤثر بر بــروز خطاهـاى دارويسى در اتـاق عمـل شـامل

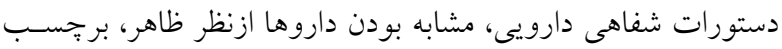
نامناسب داروها، دانش اندى درزمينه داروها، استرس كروه درمان و اعمال جراحى اورزانسى مىباشند." به دست آوردن تصوير كلى از خطاهاى دارويى در كشورهاى درحسال توسـعه مشـكل اسـت. ايسن موضوع نه به دليل رويداد كمتر اين خطاها در اين كشورها ، كـه بــه علت علدم وجود سيسـتم ثبـت و كَزارش دهـى صسحيح و كمبـود مطالعات تحقيقى در اين زمينه است. در كشور ما اخرجه هنوز آمـار مدونى از ميـزان خطاهــاى دارويسى در دسـت نيسـت، كارشناسـان

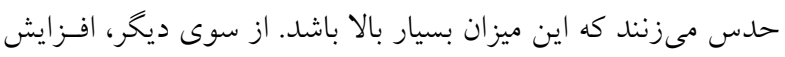

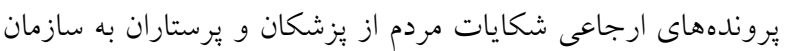

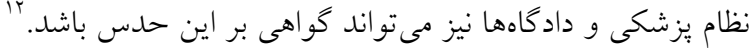

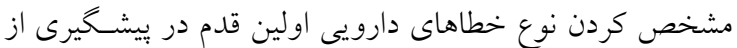
بروز خطاست. كاهش خطاهـاى دارويـى بـهـ دليـل افـزايش امنيـت بيماران از اهميت زيادى برخوردار مىباشد. از طرفى به دليل كمبود

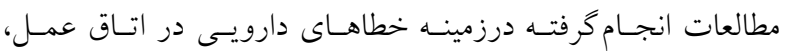

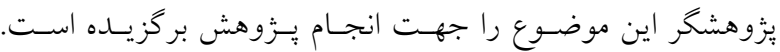

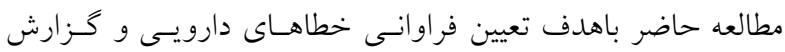
خطا طراحى شد.ارتباط بروز خطا با برخى مشخصـهـهـى فـردى و

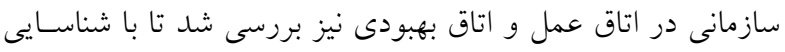

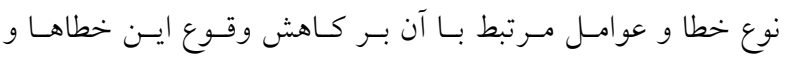
عوارض ناشى از آن بر بيماران قدم مـؤثرى برداشـته شـود و بـــين

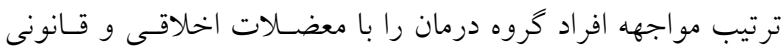
ناشى از اين خطاها كاهش دهد.

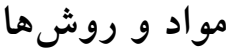

مطالعه حاضر از نوع توصيفى تحليلى است كـه در سـال ه9ب1

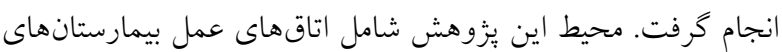
دانشگاه علوم يزشكى البرز و جامعه يـزّوهش شـامل كليـه كاركنـان شاغل در اتاقهاى عمل بيمارستانهاى دانشخاه علوم يزشـكى البـرز بودند. نمونه يزوهش شامل كارشناس بيهوشى، كارشناس اتاق عمل، برستاران شاغل در بخش اتاق عمل يا اتـاق بهبــودى بودنـــــ معيـار
خطاهاى يزشكى از جالشهاى مهم تهايد يلدنــده نظـام سـلامت در همه كشورهاست. از شايعترين خطاهـاى بزشـكى شــاختهشـــه خطاهـاى دارويسى مسىباشــد.' بــروز خطاهـاى دارويسى مسى توانسـ مشكلات جدى در سلامت عمومى به وجود آورد و تهايدى بـراى

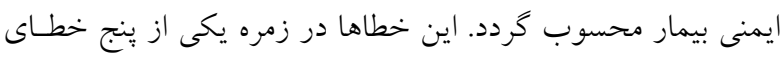

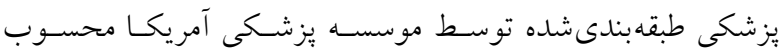
مى شوند. خ خطاهاى دارويى علاوه برافزايش هزينه هـاى بيمارستانى مى تو انند منجر به صدمات جدى و حتسى مـرى بيمـاران شـوند. بـا توجه به اينكه • اتا م| درصد از تمامى صدمات بيمارستانى ناشسى

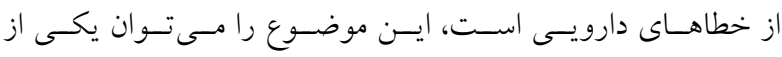

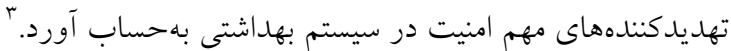
خطاهاى دارويى شايع شامل اشتباه در تجويز دارو، عدم رعايت صحيح زمان دادن دارو، رعايت نكردن راه صحيح تجويز دارو، دادن دارو به ميزان بيش از دستور تجـويز شـده، اشـتباه در محاسـبه دوز

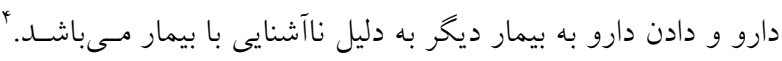

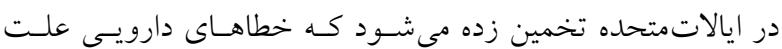

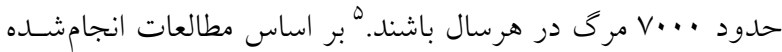

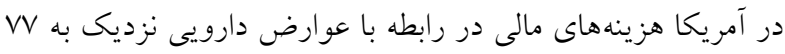

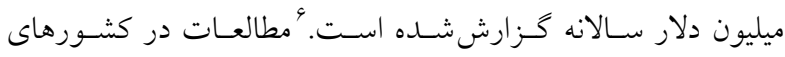
ارويايى نشان داده است كه 19 تا ب Y درصد بيمـاران بسـترى دجهـار

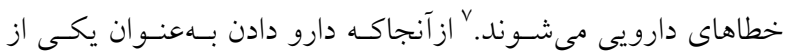
وظايف مهم و متداول يرستاران است، مستلزم مهارت، فن و دانسش ويزٔاى جهت رسيدگى به مددجو مىباشد. عـاوه بـر برسـتاران، متخصصسين بيهوشى و تكنيسين هـاى بيهوشى( تحت هدايت متخصصين بيهوشى) نيز مسـئوليت رسـاندن

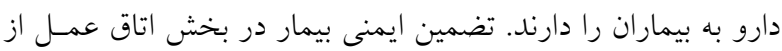
اهميت زيادى برخوردار مىباشد. انواع خطاهايى كه در اتـاق عمـل رخ ميدهند شامل بيمـار اشـتباه، محسل جراحسى اشـتباه، بروسـيجر اشتباهى و خطاهاى دارويى مى باشند. محيط جراحى آمادگى ايجـاد

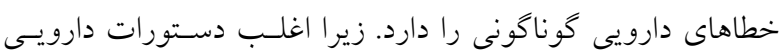

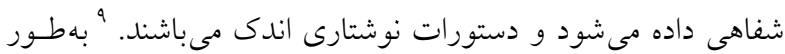
كل در هر سبا تجويز داروى بيهوشى، يـى مـورد خطـا كـزارش 
شد كه هر زمان كه تمايـل نداشـته باشـند مسى توانتـــ از شـركت در

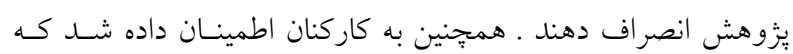

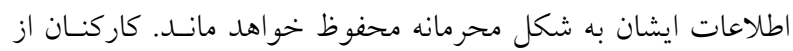

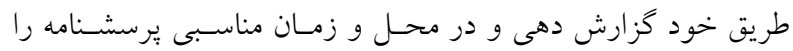

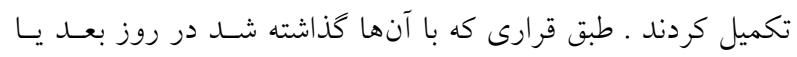

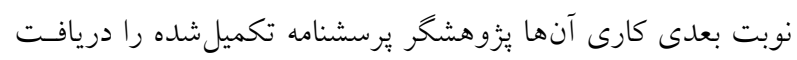

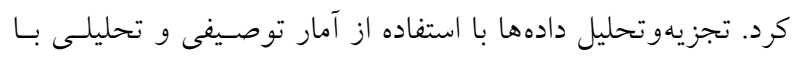
آزمونهاى آمارى كاى دو، آزمون دقيـق فيشـر و تـى تسـت انجـام

\section{يافتهها}

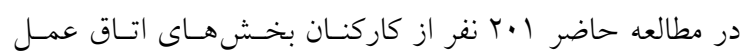

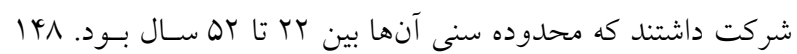
نفر زن( ) ن/

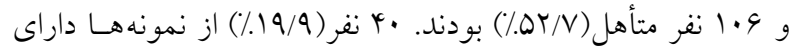

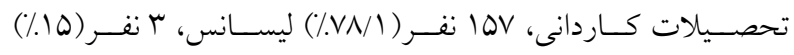
فوقليسانس و يك نفر (ه/•) يزشك متخصص بودند. از اين تعداد

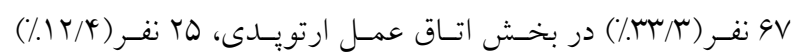

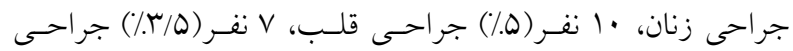

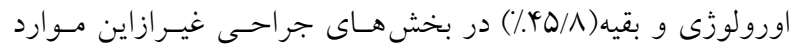

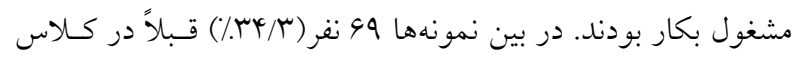

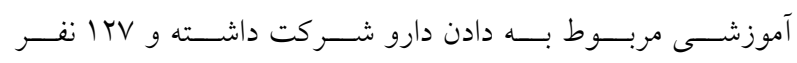

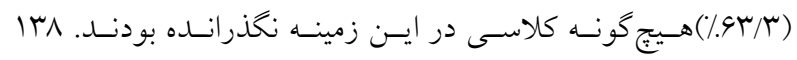

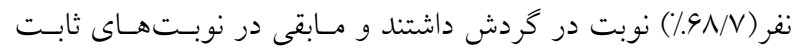

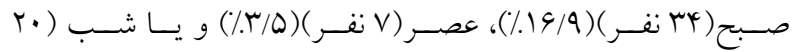
نفر)( • (1\%) مشغول بكار بودند. در بين نمونه ها ازنظر نـوع اسـتخدام 49 ييمانى( ( ب/

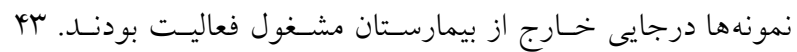

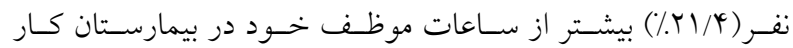

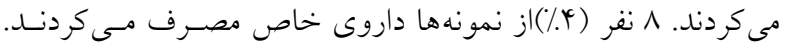

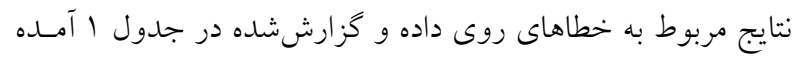

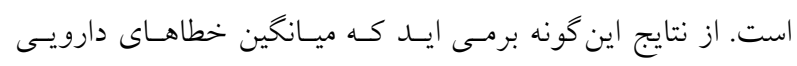

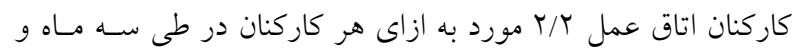

ورود به مطالعه شامل كاركنانى مى باشد كـه مسـئوليت دارودرمـانى داشته و بيشتر از سه ماه در اتاق عمل مشغول به كـار بودنــــ .معيـار خروج كاركنانى كه كمتر از سه ماه در اتاق عمـل مشـغول بـه كـار

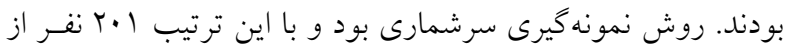

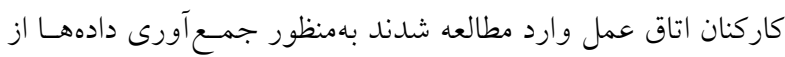

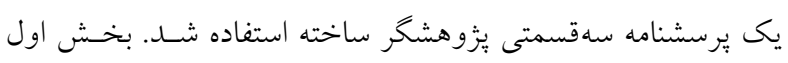

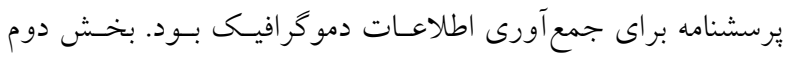

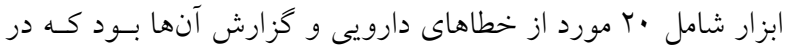
طى سهماهه كذشته براى كاركنان اتاق عمل بيش آمده است. در ايسن قسمت كاركنان اتاق عمل براى هر يك از كويه ها در ستون "تعداد

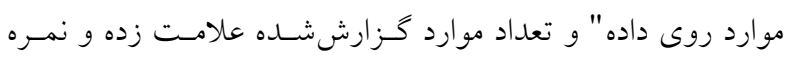
كسبشده از اين بخش، براى وقوع و كزارش خطــا از صـفر (عـدم

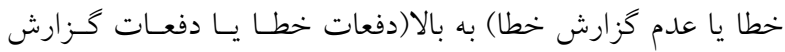
خطا) بوده است. بخش سوم يرسشنامه شامل شرايط كسارى مربـوط

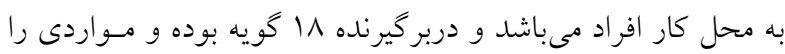
شامل مىشود كه كاركنان اظهار مىدارند در محل كار خود بـا بـا آنهـا

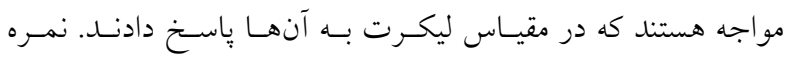
كسبشده از اين بخش بين VY- · مىباشد كه از شرايط مسـاعد بـا

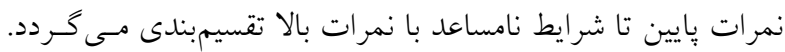

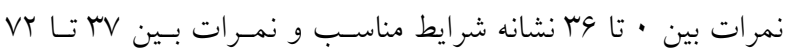

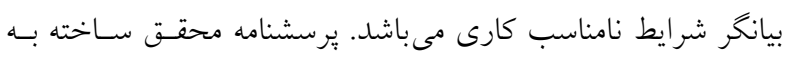

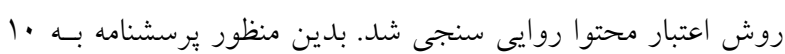
نفر از متخصصين ارسال و طبق نظرات آنهـا ميـزان روايسى محتـوا

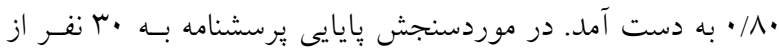

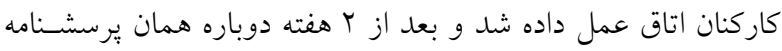

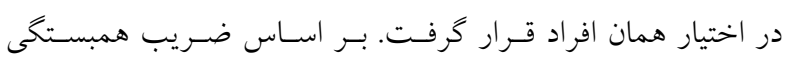

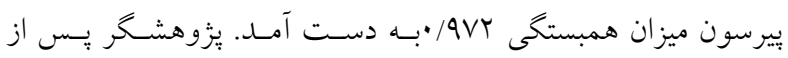

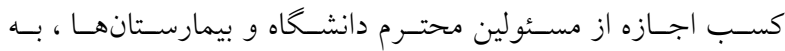
بيمارستانهاى مربوطه مراجعه كرده و با اجازه مسـئولان مـــتبط، از بخش هاى اتاق عمل بيمارستانها، نمونههـاى مـوردنظر خـود رادر

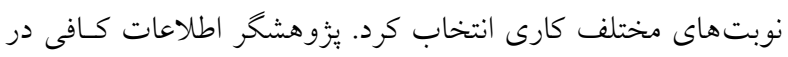

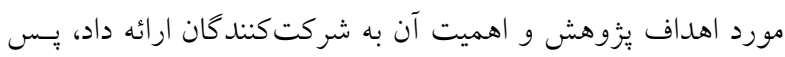

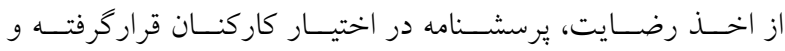
توضيحات لازم در مورديزوهش داده شد و به كاركنان اطمينـان داده 


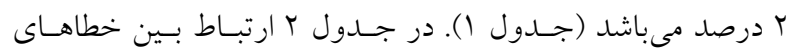

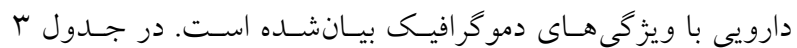
ارتباط خطاهاى دارويى با ويزگى هاى شغلى بيانشده است. جــول † ارتباط بين خطاهاى دارويى روى داده و گزارش شــده بـا شــايط

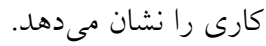

ميانخين گزارش خطاهاى دارويى 9.

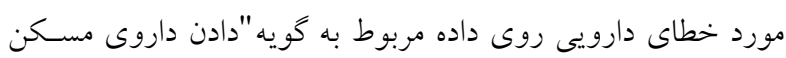

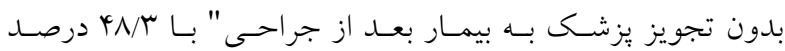
مىباشد و در بخش مربوط بـهـ گـزارش خطاهـاى رخداده بيشـترين

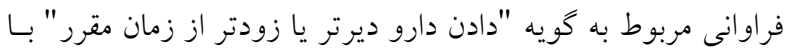

جدول ا: ميزان خطاهاى دارويى روى داده و گزارششده توسط كاركنان اتاق عمل

\begin{tabular}{|c|c|c|c|c|c|}
\hline \multicolumn{2}{|c|}{ كزارش موارد } & \multicolumn{2}{|c|}{ موارد روى داده } & \multirow{2}{*}{\multicolumn{2}{|c|}{ كويه }} \\
\hline درصد & ت تعداد & درصد & ت تعداد & & \\
\hline 1 & r & r & 9 & دادن دارو به بيمارى غير از بيمار هدف & 1 \\
\hline$\cdot / 0$ & 1 & $V / \Delta$ & 10 & دادن داروى اشتباه به بيمار & r \\
\hline r & $r$ & $\mid r / 4$ & rq & دادن دارو ديرتر يا زودتر از زمان مقرر & $r$ \\
\hline . & . & $\Lambda / \Delta$ & iv & ندادن داروى تجويزشده به بيمار & r \\
\hline$\cdot / 0$ & 1 & $19 / 4$ & ma & تزريق سريع دارويى كه بايد بهآرامى تزريق شود & 0 \\
\hline 1 & r & $1 V / 9$ & re & عدم انجام اقدامات ضرورى در مورد داروهايى كه مستلزم توجهات ويزه(كرفتن نبض، فشارخون و..) هستند & 4 \\
\hline$\cdot / 0$ & 1 & $1 \cdot / 4$ & rl & مخلوط كردن دو يا جند دارو در يك سرنگ بدون توجه به تداخلات دارويى & $\checkmark$ \\
\hline . & $\cdot$ & . & $\cdot$ & روش نادرست رساندن دارو به بيمار & $\wedge$ \\
\hline$\cdot / 0$ & 1 & $r / \Delta$ & $\checkmark$ & دادن دارو كمتر يا بيشتر از دوز تجويزشده & 9 \\
\hline . & $\cdot$ & $r / \Delta$ & $\checkmark$ & رقيق نكردن دارويى كه بايد رقيق شود & $1 \cdot$ \\
\hline . & $\cdot$ & $\Lambda / \Delta$ & IV & حل كردن داروها قبل از زمان مقرر & 11 \\
\hline · & . & $r / \Delta$ & $\checkmark$ & عدم توجه به برجسب داروها ازنظر نوع دارو & ir \\
\hline 1 & r & $r / \Delta$ & 9 & عدم توجه به برجسب داروها ازنظر تاريخ انقضا دارو & 14 \\
\hline . & . & $\uparrow V / Q$ & 99 & آماده كردن دارو توسط افراد ديخر & 14 \\
\hline 1 & r & $\mu \wedge / r$ & १V & دادن داروى مسكن بدون تجويز يزشك به بيمارى كه بعد از جراحى درد دارد & 10 \\
\hline$\cdot$ & $\cdot$ & $\cdot / 0$ & 1 & استفاده از حلال اشتباه جهت رقيق كردن داروها & 19 \\
\hline$\cdot$ & . & $11 / 9$ & ry & استفاده از يك سرنخ جهت رساندن دارو به جند بيمار & IV \\
\hline$\cdot$ & $\cdot$ & $9 / 0$ & ir & استفاده از يك سرنح جهت رساندن جِند دارو به يك بيمار & $1 \wedge$ \\
\hline . & $\cdot$ & $\cdot / 0$ & 1 & استفاده از بتادين سبز جهت يربٍ اوليه يوست & 19 \\
\hline$\cdot$ & $\cdot$ & $\cdot / 0$ & 1 & استفاده از بتادين قهوه اى جهت رنخ كردن يوست & r. \\
\hline & $\cdot / \cdot 9$ & & $r / r$ & ميانخين به ازاى هريك از كاركنان در طى سه ماه & \\
\hline
\end{tabular}


جدول r: ارتباط بين خطاهاى دارويى با ويزكى هاى دموكرافيك

\begin{tabular}{|c|c|c|c|c|c|}
\hline \multicolumn{2}{|c|}{ كَزارششده } & \multicolumn{2}{|c|}{ روى داده } & \multirow[t]{3}{*}{ خطاهاى دارويى } & \multirow[b]{2}{*}{ متغير } \\
\hline sig & تعداد & sig & تعداد & & \\
\hline & & & & & جمعيت شناختى \\
\hline \multirow[t]{3}{*}{ - Nar } & IFV & . Mar & 140 & زن - ت ان & جنسيت \\
\hline & or & & or & مرد & \\
\hline & $\wedge \vee$ & & 19 & مجرد & وضعيت تا هل \\
\hline \multirow[t]{2}{*}{$\% 40$} & 1.9 & - /AYK & 1.0 & متأهل & \\
\hline & r. & & r. & كاردانى & سطح تحصيلات \\
\hline.$/ .4 v$ & 109 & - NYYK & lor & ل ليسانس & \\
\hline \multirow[t]{3}{*}{.$/ .14$} & $\wedge$ & $\cdot / 4 \Delta r$ & $\wedge$ & بلى بلى & مصرف داروى خاص \\
\hline & 194 & & 19. & خير & \\
\hline & 119 & & 114 & كمتر از بr سال & 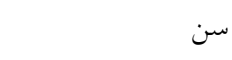 \\
\hline \multirow[t]{2}{*}{.$/ . r q$} & $9 \pi$ & $\cdot / \cdot V r$ & $4 r$ & r r تا re سال & \\
\hline & YI & & rI & بالاتر از بع سال & \\
\hline
\end{tabular}

جدول r: ارتباط بين خطاهاى دارويى با ويزگى هاى شغلى

\begin{tabular}{|c|c|c|c|c|c|}
\hline \multicolumn{2}{|c|}{ كزارش ك } & \multicolumn{2}{|c|}{ روى داده } & \multirow{2}{*}{\multicolumn{2}{|c|}{ 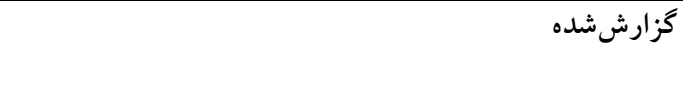 }} \\
\hline sig & تعداد & sig & تعداد & & \\
\hline \multirow[t]{5}{*}{.1099} & $9 \mathrm{~V}$ & $\cdot / \cdot Y V$ & 94 & جراحى ارتويدى & بخش اتاق عمل \\
\hline & ro & & ro & جراحى زنان & \\
\hline & 1. & & 1. & قلب & \\
\hline & v & & v & اورولوزى & \\
\hline & 91 & & 9. & 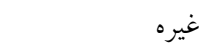 & \\
\hline \multirow[t]{2}{*}{ / $/ 994$} & 99 &.$/ 191$ & 99 & 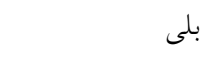 & كذراندن كلاس آموزشى درزمينه دارو دادن \\
\hline & 174 & & KF & خير & \\
\hline \multirow[t]{4}{*}{$. / 4 \mid r$} & irv &.$/ 1 r a$ & iro & مر خردش & نوع شيفت \\
\hline & re & & re & 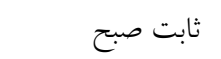 & \\
\hline & $v$ & & $v$ & ثابت عصر & \\
\hline & $r \cdot$ & & $r \cdot$ & ثابت شب & \\
\hline \multirow[t]{2}{*}{$\cdot / \varphi \Delta \Lambda$} & 94 & $\cdot / 199$ & 99 & 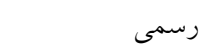 & نوع استخدام \\
\hline & 49 & & 4 & 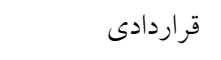 & \\
\hline \multirow[t]{2}{*}{$\cdot / \cdot 14$} & $v$ & $\cdot / 091$ & 9 & 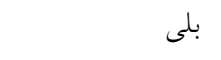 & اشتغال در خارج از بيمارستان \\
\hline & $19 \pi$ & & 194 & 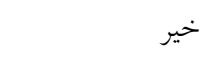 & \\
\hline \multirow[t]{3}{*}{$\cdot / \Gamma V \Delta$} & iry & $\cdot \cdot r+$ & irt & كمتر از • ل اسال & سابقه كار \\
\hline & $\Delta \wedge$ & & $\Delta \wedge$ & بين • ا تا •r سال & \\
\hline & 10 & & 10 & بيشتر از •r سال & \\
\hline \multirow[t]{3}{*}{ •/AKr } & rTo &.$/ 114$ & irr & كمتر از V سال & سابقه كار در اين بيمارستان \\
\hline & $\mu_{\Lambda}$ & & $\varphi_{\Lambda}$ & بين V تا \& 1 سال & \\
\hline & ri & & r & بيشتر از 1 سال & \\
\hline
\end{tabular}


جدول ثا: ارتباط بين خطاهاى دارويى روى داده و گزارششده با شرايط كارى

\begin{tabular}{|c|c|c|c|c|c|}
\hline sig & انحر اف معيار & ميانگين & فر اوانى & شرايط كارى & خطاهاى دارويى \\
\hline \multirow[t]{2}{*}{$\cdot / \cdot \uparrow \Lambda$} & $G / V 4 \ldots r$ & $r / 1 \cdot 90$ & M & مناسب & موارد روى داده \\
\hline & Q/YYTIT & Q/VG|r & 100 & نامناسب & \\
\hline \multirow[t]{2}{*}{$\cdot / \cdots$} & $\cdot / I V k \cdot \Lambda$ & $\cdot / \cdot r \cdot r$ & r & مناسب & موارد گزارش شده \\
\hline & $1 / 41$ FOV &.$/$ TYYQ & 100 & نامناسب & \\
\hline
\end{tabular}

دارويى در اين مطالعه با مطالعات ذكرشده دانست. يافتههـا نشـان داد كـهـ ميـانخين گـزارش خطاهـاى دارويسى در بخشهاى اتاق عمل 9.> • بوده است. كه كمتر از موارد يافت شـده

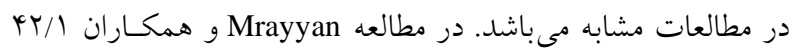

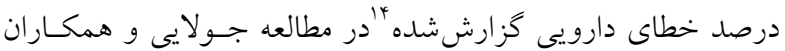

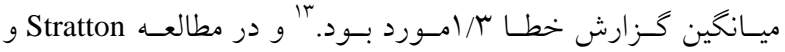

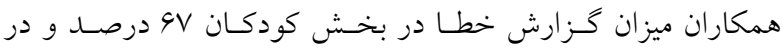

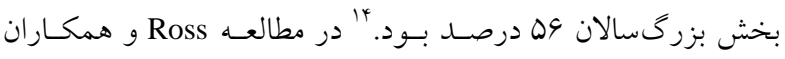

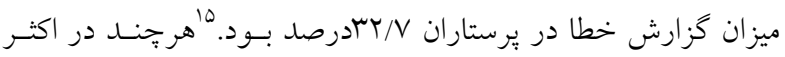
مطالعات گزارش خطاهاى دارويى بسيار كمتــ از ميـزان واقعى آن مىباشد اما كمتر بودن گزارش خطاهـاى دارويسى از خطاهـاى روى

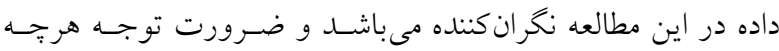
بيشتر به اين موضوع را بيان مى كند. به حداقل رساندن فاصسله بـين

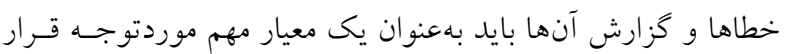

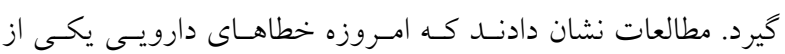

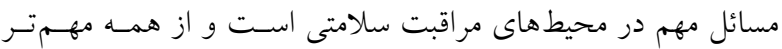
اين كه بيشخيرى از اين خطاها بستخى به كـزارش دقيـق آنهـا دارد. بنابراين بايد دلايل اجتناب در ايسن زمينـه را موردبررسسى قـرارداد.

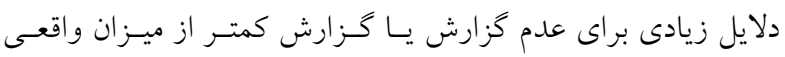

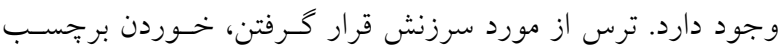
بى كفايتى، سخت بودن فرايند گزارش دهى و موانع مديريتى ازجمله

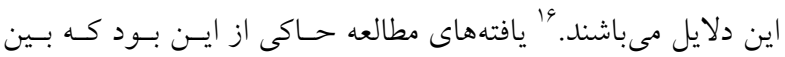

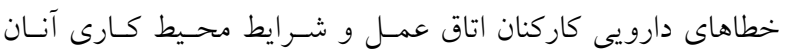

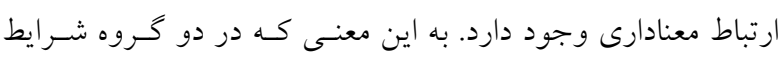
كـارى مناسـب و نامناسـب بـين مـوارد خطاهـاى رخداده اخستلاف معنى دارى وجود دارد. بنابراين به نظر مىرسد با بهبود شرايط كارى
همانطور كه در جدول r مشاهده مىشود، تعداد مـوارد رخداده و كزارششده با جنسيت رابطه معنسىارى نــارد. همجنسين تعسداد

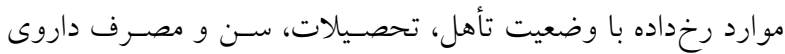

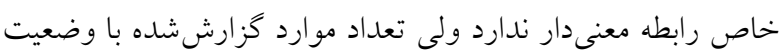
تأهل، تحصيلات، سن و مصرف داروى خاص رابطه معنى دار دارد. همانطور كه در جدول r مشاهده مى شود، تعداد مـوارد رخداده و گزارششده با كذراندن كلاس، نوع استخدام، شيفت و سابقه كـار در اين بيمارستان، رابطه معنى دارى نــدارد. تعــاد مـوارد رخداده بــا بخـش و سـابقه كـار رابطـهـ معنسى دارى دارد. ولـى تعـداد مــوارد كزارش شده با بخش و سابقه كار رابطه معنى دار ندارد. با توجه به جدول \& و با آزمون تى - مستقل در دو گروه شرايط كارى مناسب و نامناسب بين موارد رخداده و گزارششـــ اخـتلاف معنى دارى وجود دارد. - ماري

\section{بحث}

در بررسى وقوع و گزارش خطاهاى دارويى كاركنان اتاق عمـل

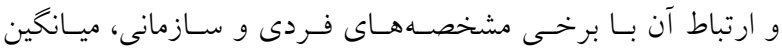
خطاهاى دارويى كاركنان اتاق عمل ب/ T و ميانحين گزارش خطاهاى دارويى 9.

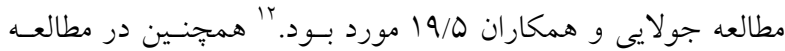
و همكاران كه در سال ه ه.rayyan مورد بود. "Stratton و همكاران در مطالعه خود كه در آمريكا انجام شد دريافتند كه ميزان خطاهاى دارويى در هـر ... ‥ بيمـار معـادل

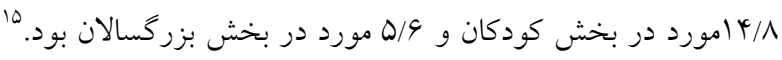

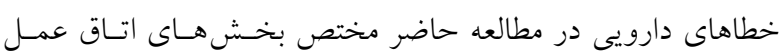
مىباشد لذا مىتوان آن را دليلى بر تفاوت فـاحش ميـزان خطاهـاى 
هستند. در مطالعه حاجى بابايى شايعترين خطاهاى دارويى عبـارت بودند از دادن جند داروى خوراكى با هم، عدم رعايت زمان مناسب تربت دارو، تزريق سريع دارويى كه بايد بـهـ آرامسى تزريـق گـــدد و دادن

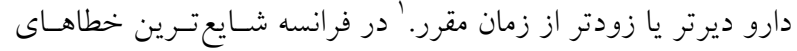
دارويى به ترتيب دوز داروى اشتباه، زمان اشتباه و روش اشتباه دارو

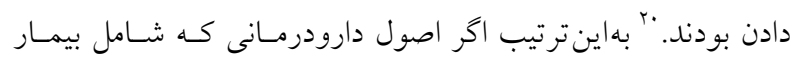
صحيح، داروى صسحيح، دوز صسحيح، راه تجـويز صسحيح و زمـان صحيح دادن دارو مىباشد را به كاركنـانى كـه مسـئول دارودرمـانى سئى

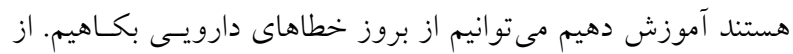

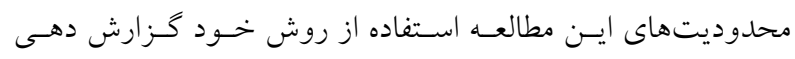
مىباشد.هرجنا به نظر مىرسد با استفاده از روش مشاهده مسىتـوان اطلاعات دقيق ترى در اين زمينه به دست آورد، ولى روش مشـاهده نيز خـود محسدوديتهـايى دارد كـه در اغلـب مطالعـات داخلـى و بين المللى از همين روش استفادهده است.

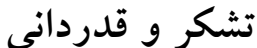

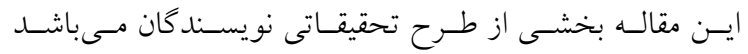

بدينوسيله مجريان طرح از معاونت محترم يزوهشى دانشخاه علسوم يزشكى و مسئولين محترم بيمارستانهاى دانشخاه علوم بزشكى البرز و از كاركنان محترم اتاق عمل كه با مشاركت خود امكان انجام طرح

$$
\text { را مهيا نمودند، تقدير و تشكر مىنمايند. }
$$

\section{References}

1. Sangjera I, Franklin B, Dhillon S. The attitudes and beliefs of healthcare professionals on the causes and reporting of medication errors in a UK intensive care unit. Journal compilation the association of anesthetists of great Britain and Ireland. 2007;62:53-61.

2. Mrayyan M, Shishani K, Al-Faouri I. Rate, cause and reporting of medication errors in Jordan: nurses "perspectives. Journal of Nursing Management. 2007; 15: 659-70.

3. Vincent C, Neale G, Woloshynowych M. Adverse events in British hospitals: preliminary retrospective record review. BMJ. 2001;322(7285):517-9.

4. Pazokian M, Zagheri Tafreshi M, Rassouli , M. Factors Affecting Medication Errors from Nurses' Perspective:
بتوان ميانخين خطاهاى دارويى را در بين كاركنـان كـاهش داد. ايسن

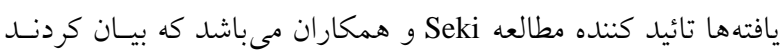
شرايط كارى منجر به ايجاد خطاهـاى بـالينى مسىشـود. " هم:جنسين مطالعه جولايى و همكاران نيز بيان كرد كه ميانخين تعـداد خطـا در شرايط كارى مساعد و نامساعد تفاوت معنادارى دارنــد. با هم:جنـين Reason در مطالعه خود نشان داد كه شرايط كارى مثل كمبود وقت،

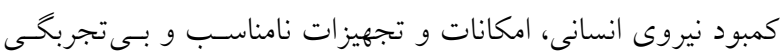
موجب افزايش فعاليتهاى بالينى غير ايمن و بروز خطاهاى بـالينى

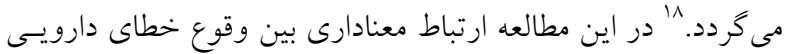
با نوع بخش و سابقه كارى كاركنان وجـود داشـت. درحسالى كـه در مطالعه حاجى بابايى و همكاران تفاوت معنادارى در اين زمينه يافت نشد.' در مطالعه Sheu و همكــاران بـين وقـوع خطـا و سـابقه كـار يرستارى و نوع بخش ارتباط معنادارى گزارش شد 19 كه از اين نظـر

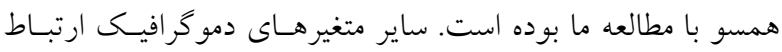
معنادارى با ميزان خطاهاى رخداده نداشتند. درحسالى كـه در مطالعـه حاجى بابايى دو متغير جنسيت و كذراندن كلاس آموزشى درزمينـه دارو دادن با خطاهاى دارويى ارتباط معنادار آمـارى داشـتند.' دليـل دوريل اين تفاوت مىتواند در ارتباط با جامعه مورديزّوهش باشد كه در دو

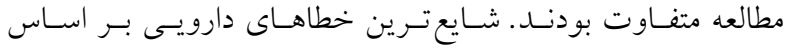
يافته هاى اين مطالعه عبارت بودند از: دادن داروى مسكن به بيمارى كه بعد از جراحى درد دارد، آماده كـردن دارو توسـط افـراد ديخــ، تزريق سريع دارويى كه بايد بهآرامس تزريـق گـــدد و عسدم انجــام اقدامات ضرورى در مـورد داروهـايى كـه مسـتلزم توجهـات ويسزّه

Lessons Learned. Iranian Journal of Medical Education. 2013; 13 (2) :98-113. [In Persian].

5. Hanna G, Levine W. Medication safety in the perioperative setting. Anesthesiol clin. 2011;29(1):13544.

6. Grissinger M, Kelly K. Reducing the risk of medication errors in women. Journal of Womens Health. 2006;14(1):61-7.

7. Johnstone MJ, Kanitsaki O. the ethics and practical importance of defining, distinguishing and disclosing nursing errors: a discussion paper. Int J Nurs Manage 2000; 31(11): 21-2. 
8. Alanko K, Nyholm L. Another Medication Error. A literature review of contributing factors and method to prevent medication error [Dissertation]. Helsinki; 2007.

9. The Joint Commission. Universal protocol for preventing wrong site, wrong procedure and wrong surgery person. Oakbrook Terrace(IL): Joint Commission; 2009. Availableat:http://www.jointcommission.org/PatientSafet y/UniversalProtocol. Retrieved April 30, 2010.

10. Merali R1, Orser BA, Leeksma A, Lingard S, Belo S, Hyland S. Medication safety in the operating room: teaming up to improve patient safety. Healthc Q. 2008;11(3):54-7.

11. Becker SC \& Hicks RW. Medication Errors in the Operating Room. U.S. Pharmacopeia. Available at: www.usp.org/hqi/patientSafety/resources/posters/posterO peratingRoom.html. Accessed February 1, 2012.

12. Jolaee S, Hajibabaee F, Peyravi H, Haghani H. Nursing medication errors and its relationship with work condition in Iran University of Medical Sciences. IJME. 2009;3 (1):65-76.

13. Mrayyan M, Shishani K, Al-Faouri I. Rate, cause and reporting of medication errors in Jordan: nurses "perspectives. Journal of Nursing Management 2007; 15: $659-70$.
14. Stratton KM, Blegen MA, Pepper G, Vaughn T. Reporting of Medication Errors by Pediatric Nurses. Journal of Pediatric Nursing 2004; 19: 385- 92.

15. Ross LM, WallaceJ, Paton JY. Medication errors in a pediatric teaching hospital in UK: five years operational experience. Arch Dis child 2000, 83(6); 492-7.

16. Anoosheh M, Ahmadi F, Faghihzadeh S, Vaismoradi M. Survey of Predisposing Causes of Working Errors in Nursing Cares from Perspective of Nurses and Their Mangers Perspectives. Iranian Journal of Nursing 2007; 20(51): 25-36. [In Persian].

17. Seki Y, \& Yamazaki Y. Effects of working conditions on intravenous medication errors in Japanese hospital. Journal of Nursing Management 2006; 14: 128-39.

18. Reason J. Human error: models and management. BMJ 2000; 320(7237): 768-70.

19. Sheu SJ, Wei IL, Chen $\mathrm{CH}$, Yu S. Using snowball sampling method with nurses to understand medication administration errors. Journal of Clinical Nursing 2008; $1-12$.

20. Tissot E, Cornette C, Limat S, et al. Observational Study of potential risk factors of medication administration errors. Pharmacology World Science 2003; 25: 264-68. 